\section{Minerals-, glassy-, globular opaque and fluid inclusions from metamorphic recrystallized "MVT" sulfide mineralization from Blazna- Guşet prospect, Rodna Mountains, Romania.}

\section{IOAN PINTEA ${ }^{1}$, SORIN SILVIU UDUBASA ${ }^{2}$, EDUARD GHINESCU $^{1}$, MARIA LIDIA NUTU ${ }^{3}$, ELENA LUISA IATAN $^{3}$ AND ION BERBELEAC ${ }^{3}$}

${ }^{1}$ Geological Institute of Romania

${ }^{2}$ University of Bucharest, Department of Mineralogy

${ }^{3}$ Institute of Geodynamics of Romanian Academy

Presenting Author: sorin.udubasa@gmail.com

The "MVT"-type of Upper Precambrian metamorphosed Pb$\mathrm{Zn}$ mineralization from Blazna-Guşet prospect in the Eastern Carpathians contains various minerals, transparent and opaque phases together with fluid inclusions. Cymrite $\left(\mathrm{BaAl}_{2} \mathrm{Si}_{2} \mathrm{O}_{8} \cdot \mathrm{OH}\right)$, chalcopyrite, pyrrhotite, Fe-poor sphalerite, galena, and intercalations of silicate, graphite, and quartz are present in the Carbonate Formation [1]. Prograde are microminerals inclusions (possible halite, anhydrite, barite, calcite, etc.) and silicate glassy-like inclusions, sulfide grains, and/or globular trails of medium-grade amphibolitic facies. Retrograde are the trails of aqueous-carbonic fluid inclusions and solid stepdaughter aggregates.

Recrystallization of sphalerite by partial melting concentrates Germanium from $650 \mathrm{ppm}$ up to $70 \mathrm{wt} \%$ in Ge-minerals [2]. Germanite from the Blazna-Guşet ore deposit shows variable morphological aspects, reminding zircon and/or apatite microcrysts, in short prismatic, tubular, and barrel forms of brownish color in yellowish sphalerite [3]. Its presence vs. synthetic Gadolinium gallium garnet (GGG) from RRUFF $\left[\mathrm{Gd}_{3} \mathrm{Ga}_{2}\left(\mathrm{GaO}_{4}\right)_{3}\right]$ was preliminarily indicated by Raman spectroscopy (Fig. 1). Genetically, it is emphasized that germanite was formed "in-situ" by removing Ge and/or (Gd, Ga) from sphalerite lattice during metamorphic recrystallization.

Fig.1. Raman spectra of germanite $\left(\mathrm{Cu}_{13} \mathrm{Fe}_{2} \mathrm{Ge}_{2} \mathrm{~S}_{16}\right)$ vs. synthetic Gadolinium gallium garnet (GGG) from RRUFF $\left[\mathrm{Gd}_{3} \mathrm{Ga}_{2}\left(\mathrm{GaO}_{4}\right)_{3}\right]$ in recrystallized sphalerite from the BlaznaGuşet ore deposit.

References:

[1] Udubasa, Nedelcu, Andar \& Andar (1983), Miner. Dep. $18,519-528$.

[2] Cugerone, Cenki-Tok, Oliot, Munoz, Chauvet, Barou, Kouzmanov, Salvi, Motto-Ros \& Le Goff (2019), $15^{\text {th }}$ SGA Biennial Meeting 2019, vol 4, 1669-1672.

[3] Pintea (2015), Rom. Jour. Earth Sci., 205p (in review).

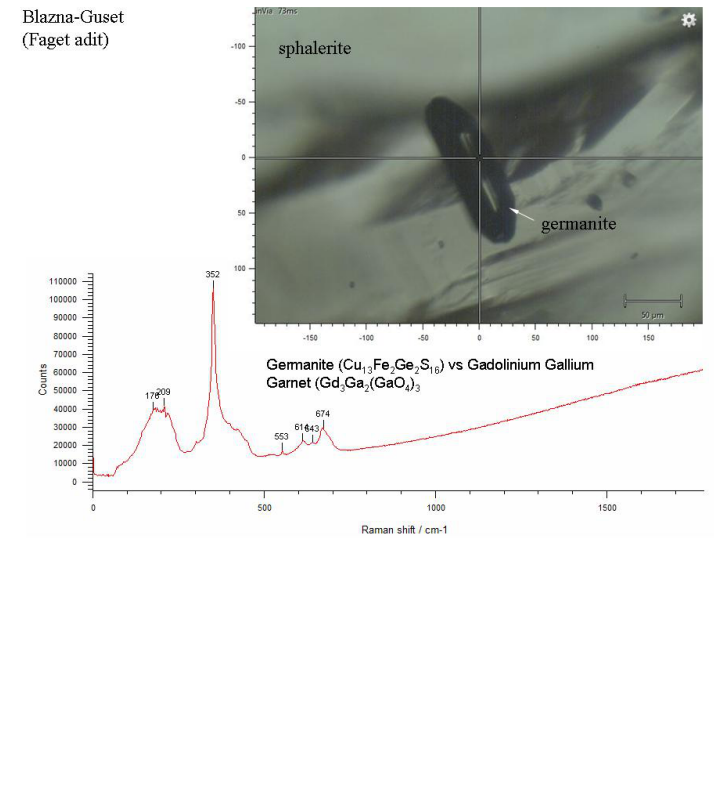

